\title{
Evaluating a Wetness-based Warning System and Reduced- risk Fungicides to Manage Sooty Blotch and Flyspeck of Apple
}

\author{
M. Babadoost, ${ }^{1}$ \\ P.S. McManus, ${ }^{2}$ \\ S.N. Helland, ${ }^{3}$ and \\ M.L. Gleason ${ }^{3}$
}

AdDITIONAL INDEX WORDS. Zygophiala jamaicensis, fungal disease, disease management

Summary. The effectiveness of a disease-warning system and efficacy of reduced-risk fungicides for management of sooty blotch (Peltaster fructicola, Leptodontium elatius, Geastrumia polystigmatis) and flyspeck (Schizothyrium pomi) (SBFS) of apple (Malus $\times$ domestica) were evaluated in Illinois, Iowa, and Wisconsin in 2001 and 2002. Warning systemtimed applications of the second-cover fungicide spray occurred when 175 $h$ of leaf wetness had accumulated; wetness data were derived either from a sensor placed beneath the canopy of apple trees (on-site) or according to remotely sensed estimates. In replicated experiments, using sensor measurements as inputs to the warning system saved one to three (mean 1.8) and zero to four (mean 2.3) fungicide sprays per season in 2001 and 2002 , respectively. Because remotely estimated wetness hours accumulated more rapidly than did on-site measurements, the warning system using remotely sensed wetness data saved

Use of trade name does not imply endorsement of the product and does not imply its approval to the exclusion of the other products that also may be suitable. This research was supported in part by a grant from Crops at Risk Program-CSREES, USDA.

${ }^{1}$ Department of Crop Sciences, University of Illinois, Urbana, IL 61801; babadoos@uiuc.edu; to whom reprint requests should be addressed.

${ }^{2}$ Department of Plant Pathology, University of Wisconsin, Madison, WI 53706; psm@plantpath.wisc.edu.

${ }^{3}$ Department of Plant Pathology, Iowa State University, Ames, IA 50011; sarathom@iastate.edu and mgleason@iastate.edu. 
only zero to one (mean 0.3 ) and zero to two (mean 0.7 ) sprays per season in 2001 and 2002, respectively. SBFS incidence in the integrated pest management (IPM) plots did not differ significantly from that of conventional calendar-based fungicide sprays plots in 11 of 12 site-years. When on-site wetness measurements were used in demonstration trials at 14 cooperating commercial orchards in 2001 and 2002, the SBFS warning system saved one to six (mean 2.6) and two to seven (mean 3.1) sprays per season, respectively. Incidence of SBFS in IPM plots did not differ significantly from trees managed with cooperating growers' conventional fungicide schedules in 16 of 28 siteyears. The on-site warning system was more consistently successful in Illinois and Iowa than it was in Wisconsin in both replicated experiments and in cooperating commercial orchards. The reduced-risk fungicides kresoximmethyl and trifloxystrobin provided control of SBFS equal to conventional fungicides (benomyl or thiophanatemethyl) in all trials. Potassium bicarbonate controlled SBFS less effectively than either conventional fungicides on a calendar-based or disease-warning schedule, or treatments incorporating reduced-risk fungicides.

S ooty blotch $(\mathrm{SB})$ of apple is a disease complex caused by the fungi Peltaster fructicola Johnson, Leptodontium elatius (G. Mangenot) De Hoog, Geastrumia polystigmatis Balista \& M.L. Farr, and other fungi (Johnson et al., 1996; Williamson and Sutton, 2000). Flyspeck (FS) is caused by the fungus Schizothyrium pomi (Mont. \& Fr.) Arx. (anamorph: Zygophiala jamaicensisE. Mason)(Williamson and Sutton, 2000). SB and FS are the most common summer diseases of apple (Malus $\times$ domestica Borkh) in the midwestern United States (Bessin et al., 1998) and commonly occur together on apple fruit (Williamson and Sutton, 2000). The fungi blemish the fruit cuticle, which can result in up to $100 \%$ of the crop being unmarketable as fresh fruit and increase desiccation of fruit during storage (Rosenberger, 1994).

Most growers in the midwestern U.S. apply three to eight calendar-based protectant fungicide sprays per season to control SBFS (Weinzierl et al., 2002). The application of conventional fungicides on a calendar-based spray schedule is unsustainable for several reasons.
First, the Food Quality Protection Act (FQPA) restrictions may impact disease management most critically during the mid- to late-season period, when SBFS is active. Pesticides applied during this period are more likely to leave residue on apples at harvest than early season sprays. As a result, older fungicides [i.e., ethylene bisdithiocarbamates(EBDCs)] that have been the mainstay of SBFS management are at higher risk of being restricted or banned, as they come up for periodic review under FQPA (Williamson and Sutton, 2000). Second, severe economic pressures are forcing apple growers to cut pest control costs (Gleason et al., 1994). A fungicide program for control of summer diseases of apple has a cost of about $\$ 15$ to $\$ 25 /$ acre ( $\$ 37.06$ to $\$ 61.77 / \mathrm{ha})$ per spray (Gleason et al., 1994). Third, many broad-spectrum fungicides are acutely toxic to nontarget organisms (Cooley et al., 1995). Fourth, resistance development has reduced the efficacy of benzimidazole fungicides, which are commonly used to control summer diseases of apple (Cooley et al., 1995). Several alternative tactics that reduce pesticide use have been proposed, but these strategies will be adopted only if they provide acceptable fruit yield and quality (Cooley and Autio, 1997).

The incidence and severity of SB and FS are dependent on moisture conditions in the orchard. Kirby (1954) reported that the amount of SB in Pennsylvania in a given year was proportional to the amount of rainfall occurring in July and, to a lesser extent, in August and September. Hickey (1960) reported that SB symptoms appeared after 8 to $12 \mathrm{~d}$ on inoculated mature fruit in a moist chamber, but appeared after 20 to $24 \mathrm{~d}$ in the field where moisture levels fluctuated. Brown and Sutton (1995) reported that symptoms of SB and FS in North Carolina appeared after 273 leaf wetness hours (LWH) (counting only of wetness periods of $\geq 4 \mathrm{~h}$ ) had accumulated following the first-cover spray (applied $10 \mathrm{~d}$ after petal fall). They suggested a threshold value of 200 to 250 accumulated LWH after the first-cover spray before the initiation of subsequent calendar-based fungicide sprays for control of SBFS. In Kentucky, Hartman (1995) and Smigell and Hartman (1997) applied a second-cover spray after $175 \mathrm{LWH}$ had accumulated following the first-cover spray, and reported that this strategy was as effective as calendar-based tim- ing of the second-cover spray for SBFS control. In addition, two to four fungicide applications were saved. The LWH used in disease-warning systems in North Carolina and Kentucky were measured with sensors placed $5 \mathrm{ft}$ ( 1.5 $\mathrm{m})$ high within the apple canopy.

Although on-site sensors are accurate, they can be labor-intensive and prone to mechanical failure. Recent commercialization of site-specific weather simulation (e.g., SkyBit, Inc., Bellefonte, $\mathrm{Pa}$.) has potential to make disease-warning systems easier to use (Gleason et al., 1997, 2000; Russo, 2000; Russo et al., 1996). Geographical information system programs estimate weather variables to within an area of 0.4 mile $^{2}\left(1 \mathrm{~km}^{2}\right)$, and deliver these data daily to the end user by electronic mail or fax at a low cost. A critical step in implementing this new technology in disease-warning systems is to validate it in field trials.

Reduced-risk strobilurin fungicides, which pose relatively low hazard to humans and the environment, are an alternative to conventional fungicides currently used for SBFS management. The strobilurin fungicides have been used to effectively control SBFS in New York and North Carolina (Rosenberger etal., 2000; Sutton etal., 2000). In addition, potassium bicarbonate fungicides, which are approved for use by organic growers, have been used effectively to control several plant diseases (Bervejilo et al., 2000; Lunden and Grove, 2002). Potassium bicarbonate provided effective control of SBFS in preliminary field trials in Wisconsin (Andrews et al., 2001).

This study was conducted to evaluate the efficacy of a wetness-based disease-warning system and reduced-risk fungicides for management of SBFS in Illinois, Iowa, and Wisconsin. Also, LWH derived from sensors in appletree canopies was compared with LWH estimates derived from remotely sensed, site-specific (SkyBit, Inc.) data. A preliminary report of this study has been published (Gleason et al., 2002).

\section{Materials and methods}

RePLICATED EXPERIMENTS. Field trials were conducted in 2001 and 2002 at three locations: University of Illinois Pomology Research Farm in Urbana, Ill.; Iowa State University Horticulture Station in Ames, Iowa; and Oakwood Fruit Farm in Richland Center, Wis. The experimental unit in Iowa was a 
two-tree block in a mixed orchard of 'McIntosh', 'Red Delicious', 'Golden Delicious', and 'Jonathan' trees. In Illinois and Wisconsin, the experimental units were two-tree blocks of 'Golden Delicious' and 'Redcort', respectively.

In 2001, the experimental design was a randomized complete block with four replications (two trees each) of seven treatments. In all treatments, trees were sprayed with fungicides through the firstcover spray to control scab, rust, and powdery mildew. Trees were sprayed with $150 \mathrm{gal}$ of water per acre (1406.7 L.ha-1), without any wetting agent, using handgun sprayers. In four treatments, second-cover and later sprays were applied on a calendar-timed basis (about every $14 \mathrm{~d}$ ). These included: conventional control of $2.2 \mathrm{oz} /$ acre (154.1 $\left.\mathrm{g} \cdot \mathrm{ha}^{-1}\right)$ a.i. benomyl [Benlate $50 \mathrm{WP}$ (DuPont, Wilimington, Del.)] plus $12 \mathrm{oz} /$ acre $\left(840.6 \mathrm{~g} \cdot \mathrm{ha}^{-1}\right)$ a.i. captan [Captan 50 WP (Arvesta Corp., San Francisco, Calif.)]; $1.2 \mathrm{oz} /$ acre (84.1 $\mathrm{g} \cdot \mathrm{ha}^{-1}$ ) a.i. kresoxim-methyl [Sovran 50 WG (BASF Corp., Research Triangle Park, N.C.)] alternated every 14 $\mathrm{d}$ with benomyl plus captan; $1.2 \mathrm{oz} /$ acre

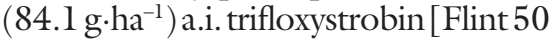
WG (Bayer Corp., Kansas City, Kans.)] alternated every $14 \mathrm{~d}$ with benomyl plus captan; and $2.5 \mathrm{lb} /$ acre $\left(2.8 \mathrm{~kg} \cdot \mathrm{ha}^{-1}\right)$ a.i. potassium bicarbonate [Kaligreen 82 WP (Toagosei Co., Tokyo)]. Two treatments based on warning systems were sprayed with benomyl plus captan at the first-cover spray. The second-cover spray was applied when about $175 \mathrm{LWH}$ had accumulated according to the on-site sensor ( of $\geq 4$ h duration) or site-specific source (SkyBit, Inc.). On-site LWHwere recorded in each orchard with Watchdog LeafWetness/Temperature Logger [WLWTL (Spectrum Technologies, Inc., Plainfield, Ill.)]. Starting with the second-cover spray, benomyl + captan were applied on a 14-d schedule for the reminder of the growing season, similar to other treatments. A nonsprayed control received no fungicides after the firstcover spray. In 2002, the reduced-risk strobilurin fungicides kresoxim-methyl was tested using the disease warning systems with both on-site and site-specific weather data. In addition, benomyl was replaced with thiophanate-methyl [Topsin-M 70 WSB (Cerexagri, Inc., King of Prussia, Pa.)] in the 2002 trial due to the impending withdrawal of registration of benomyl. Thiophanate-methyl was applied at the rate of $6.3 \mathrm{oz} /$ acre $\left(441.3 \mathrm{~g} \cdot \mathrm{ha}^{-1}\right)$ a.i.
About 2 weeks before harvest, apples were inspected independently for incidence (percent fruit infected) of SB and FS. In Iowa and Wisconsin, 50 apples selected arbitrarily on each tree ( 25 apples from the top half and 25 from the bottom half of the canopy) were inspected. In Illinois, 60 apples selected arbitrarily from each tree were inspected for incidence and rated for severity (percent surface area of fruit with SB or FS infection); five apples from the upper, middle, and lower canopies on each of the four sides (north, east, south, and west) of each tree were rated.

ON-Site WETNESS MEASUREMENTS. Hourly measurements of wetness were made from the time of the first-cover spray until accumulation of $175 \mathrm{LWH}$ at all of the research sites. LWH were recorded in each orchard with the WLWTL. The WLWTL sensor measures the degree of leaf wetness on a scale from 0 (dry) to 15 (wet). An hour was considered wet when a value of $\geq 6$ was recorded. One sensor was placed on the northern side of the canopy of one tree in each orchard about $5 \mathrm{ft}$ above the ground facing north at an angle of $45^{\circ}$ to horizontal. Data were downloaded to a computer at least once per week, and accumulated LWH were calculated.

Site-specific Weather data. Site-specific estimates were provided by SkyBit, Inc. SkyBit processes data from the U.S. National Weather Service using computer programs based on a weather model called MASS (mesoscale atmospheric simulation system) (Kaplan et al., 1982). The MASS model simulates fine scale, near-surface weather data and provides a detailed representation of mesoscale phenomena. SkyBit delivered hourly estimates ofleaf wetness $(0=$ dry, 1 = wet) for each experimental site daily by electronic mail.

Demonstration trials. The effectiveness of the on-site warning system for management of SBFS also was tested in demonstration trials at 14 cooperating commercial orchards in 2001 and 2002 (Table 4): in Illinois at Champaign, Peoria, Sidney, Sullivan, and Villa Grove; in Iowa at Cambridge, Ft. Dodge, Iowa Falls, Jefferson, and Nevada; and in Wisconsin at Cottage Grove, Fitchburg, Poynette, and Waunakee. The goal of these trials was to give growers experience with the disease-warning system and to refine and improve the system.

In each orchard, a block of eight to ten trees was used to evaluate the warning system (IPM block). One WLWTL was placed in each orchard as discussed in the field experiment. The second-cover spray (benomyl plus captan or thiophanate-methyl plus captan) was applied to the test block when 175 LWH had accumulated, whereas the rest of the orchard received the second-cover spray according to each grower's spray schedule (usually 14-d intervals). The IPM blocks received the normal spray program once the second cover-spray was initiated. At the end of the season in Iowa and Wisconsin, incidence of SB and FS were rated on 50 apples selected arbitrarily from each of the IPM trees and an equal number of trees from the same-cultivar that had received the conventional sprays. In Illinois, 60 apples selected arbitrarily from each tree were rated for incidence and severity of SB and FS using the same technique as previously described

DATA ANALYSIS. In both years, data were analyzed using analysis of variance (ANOVA), general linear model (GLM), and correlation (CORR) procedures of SAS (SAS Institute, Cary, N.C.), and comparisons were made using Fisher's protected least significant difference (LSD). Although data were analyzed in the demonstration trials as though each tree was a replication, these replications were not randomized.

\section{Results and discussion}

Disease WARNING SYSTEM. In Illinois and Iowa, use of the SBFS onsite warning system with benomyl or thiophanate-methyl plus captan saved one to four fungicide sprays compared to the conventional control calendarbased schedule (Table 1). There were no significant differences in incidence of SBFS between the two procedures (Tables 2 and 3). In 2002, using the onsite warning system with an alternation of kresoxim-methyl and thiophanatemethyl plus captan provided excellent control at all locations (Table 3 ). In Iowa, however, incidence of FS was significantly higher for the warning system treatment than the conventional treatment. The on-site SBFS disease warning system in Illinois and Iowa could save growers one or more sprays each year and is an effective IPM strategy for SBFS control.

In Wisconsin, using LWH measurements in the warning system saved three sprays over the conventional control in 2001 (Table 1), but apples from these trees had a significantly higher 
Table 1. Hours of accumulated wetness, dates of sprays, and number of sprays saved using on-site or site-specific data in a sooty blotch/flyspeck/warning system in 2001 and $2002 .^{2}$

\begin{tabular}{|c|c|c|c|c|c|c|c|c|}
\hline \multirow[b]{2}{*}{ State } & \multirow{2}{*}{$\begin{array}{c}1^{\text {st }} \text { Cover } \\
\text { spray }\end{array}$} & \multirow{2}{*}{$\begin{array}{c}2^{\text {nd }} \text { Cover } \\
\text { spray } \\
\left(\text { calendar }^{y}\right)\end{array}$} & \multicolumn{3}{|c|}{$\begin{array}{c}2^{\text {nd }} \text { Cover spray } \\
(\text { on-site })^{y}\end{array}$} & \multicolumn{3}{|c|}{$\begin{array}{l}2^{\text {nd }} \text { Cover spray } \\
\left(\text { site-specific }^{y}\right)\end{array}$} \\
\hline & & & Date & $\mathrm{LWH}^{\mathrm{x}}$ & $S S^{\mathrm{w}}$ (no.) & Date & LWH & SS (no.) \\
\hline \multicolumn{9}{|l|}{2001} \\
\hline Illinois & 17 May & l June & 22 June & 178 & 1 & 5 June & 248 & 0 \\
\hline Iowa & 16 May & 30 May & 15 June & 181 & 1 & 1 June & 177 & 0 \\
\hline Wisconsin & 28 May & 11 June & 24 July & 169 & 3 & 25 June & 233 & 1 \\
\hline \multicolumn{9}{|l|}{2002} \\
\hline Illinois & 24 May & 7 June & 19 July & 174 & 3 & 25 June & 248 & 0 \\
\hline Iowa & 23 May & 6 June & 13 Aug. & 181 & 4 & 15 July & 175 & 2 \\
\hline Wisconsin & 12 June & 26 June & 27 June & 199 & 0 & 27 June & 220 & 0 \\
\hline
\end{tabular}

${ }^{2}$ Trials were conducted at the University of Illinois Pomology Research Farm, Urbana; Iowa State University Horticulture Station, Ames; and Oakwood Fruit Farm, Richland Center, Wis.

ySecond-cover spray timing was about $14 \mathrm{~d}$ after first-cover spray (calendar); based on leaf wetness data from Watchdog dataloggers placed in orchards (on-site); or based on leaf wetness data remotely estimated for the location of each orchard (site-specific) by SkyBit, Inc. (Bellefonte, Pa.).

${ }^{x} \mathrm{LWH}=$ leaf wetness hours from the first-cover fungicide spray until application of the subsequent fungicide spray. Target threshold was $175 \mathrm{LWH}$.

${ }^{\mathrm{w}} \mathrm{SS}=$ sprays saved

Table 2. Effect of reduced-risk fungicides and a disease warning system on the incidence and severity of sooty blotch (SB) and flyspeck (FS) of apple in replicated experiments in $2001 .^{\mathrm{z}}$

\begin{tabular}{|c|c|c|c|c|c|c|c|}
\hline \multirow[b]{3}{*}{ Treatment } & \multicolumn{4}{|c|}{ Illinois $^{\mathrm{y}}$} & \multicolumn{2}{|c|}{ Wisconsin ${ }^{x}$} & \multirow{3}{*}{$\frac{\text { Iowa }^{x}}{\text { SB } / \text { FS }^{w}}$} \\
\hline & \multicolumn{2}{|c|}{ SB } & \multicolumn{2}{|c|}{ FS } & SB & FS & \\
\hline & $\begin{array}{l}\text { Incidence } \\
(\%)\end{array}$ & $\begin{array}{l}\text { Severity }^{v} \\
(\%)\end{array}$ & $\begin{array}{c}\text { Incidence } \\
(\%)\end{array}$ & $\begin{array}{c}\text { Severity } \\
(\%)\end{array}$ & & $\begin{array}{c}\text { Incidence } \\
(\%)\end{array}$ & \\
\hline Benomyl + captan (conventional) & $0.8 \mathrm{a}^{\mathrm{u}}$ & $0.03 \mathrm{a}$ & $0.4 \mathrm{ab}$ & $0.01 \mathrm{a}$ & $0.3 \mathrm{a}$ & $2.3 \mathrm{a}$ & $0.0 \mathrm{a}$ \\
\hline Benomyl + captan $\left(\right.$ on-site $\left.{ }^{t}\right)$ & $0.8 \mathrm{a}$ & $0.02 \mathrm{a}$ & $0.1 \mathrm{ab}$ & $0.02 \mathrm{a}$ & $0.2 \mathrm{a}$ & $12.7 \mathrm{ab}$ & $0.0 \mathrm{a}$ \\
\hline Benomyl $+\operatorname{captan}\left(\right.$ site-specific $\left.{ }^{\mathrm{t}}\right)$ & $0.0 \mathrm{a}$ & $0.00 \mathrm{a}$ & $0.0 \mathrm{a}$ & $0.00 \mathrm{a}$ & $1.0 \mathrm{a}$ & $4.0 \mathrm{a}$ & $0.0 \mathrm{a}$ \\
\hline $\begin{array}{l}\text { Kresoxim-methyl alternated with } \\
\text { benomyl + captan }\end{array}$ & $0.0 \mathrm{a}$ & $0.00 \mathrm{a}$ & $0.0 \mathrm{a}$ & $0.00 \mathrm{a}$ & $0.2 \mathrm{a}$ & $2.3 \mathrm{a}$ & $0.0 \mathrm{a}$ \\
\hline $\begin{array}{l}\text { Trifloxystrobin alternated with } \\
\text { benomyl + captan }\end{array}$ & $0.0 \mathrm{a}$ & $0.00 \mathrm{a}$ & $0.2 \mathrm{ab}$ & $0.00 \mathrm{a}$ & $0.1 \mathrm{a}$ & $2.6 \mathrm{a}$ & $0.5 \mathrm{a}$ \\
\hline Potassium bicarbonate & $1.0 \mathrm{a}$ & $0.03 \mathrm{a}$ & $1.5 \mathrm{~b}$ & $0.01 \mathrm{a}$ & $2.3 \mathrm{a}$ & $27.8 \mathrm{~b}$ & $7.7 \mathrm{a}$ \\
\hline Nontreated control & $4.0 \mathrm{~b}$ & $0.21 \mathrm{~b}$ & $5.0 \mathrm{c}$ & $0.22 \mathrm{~b}$ & $14.7 \mathrm{~b}$ & $54.1 \mathrm{c}$ & $62.5 \mathrm{~b}$ \\
\hline $\operatorname{LSD}(P<0.05)$ & 1.2 & 0.07 & 1.3 & 0.06 & 3.8 & 15.5 & 12.0 \\
\hline
\end{tabular}

${ }^{2}$ Trials were conducted at the University of Illinois Pomology Research Farm, Urbana; Iowa State University Horticulture Station, Ames; and Oakwood Fruit Farm, Richland Center, Wis.

${ }^{y}$ Mean percent of four replications; 120 apples per replication.

${ }^{\mathrm{x}}$ Mean percent of four replications; 100 apples per replication.

${ }^{w}$ Combined incidence of SB and FS was rated in Iowa in 2001.

v Severity = percent surface area of fruit with SB or FS infection.

"Values within each column with a letter in common are not significantly different according to Fisher's protected least significant difference $(P=0.05)$.

tSecond-cover spray timing based on leaf wetness data from dataloggers placed in orchards (on-site) or based on leaf wetness data remotely estimated for the location of each orchard (site-specific) by SkyBit, Inc. (Bellefonte, Pa.).

incidence of FS than those from the control (Table 2). In 2002, neither the on-site nor the site-specific weather data saved sprays over the conventional control (Table 1). Possible explanations for the apparent failure of the warning system against FS in 2001 include greater susceptibility of Redcort to FS than cultivars tested in Illinois and Iowa, and poor spray coverage in these trees, and different strain of FS pathogen in Wisconsin than in Illinois and Iowa. Characterization of SB and FS isolates from orchards in Illinois, Iowa, and Wisconsin using sequence analysis of the internal transcribed spacer (ITS) region of rDNA suggested that the assemblages and relative abundance of SB and $\mathrm{FS}$ fungi varies considerably among the orchards (Batzer et al., 2002a). It is possible that the FS pathogen in the Wisconsin orchard has different leaf wetness requirements for apple colonization than those in Illinois and Iowa. Characterization of FS pathogen(s) in Wisconsin and adjustment of the disease warning system for these fungi may be necessary before this system can be used with confidence.

In all three states, use of the sitespecific leaf wetness data in the diseasewarning system resulted in acceptable control of SBFS but required more sprays than did use of on-site measurements. The difference between on-site and site-specific warning systems occurred because SkyBit, Inc. consistently overestimated LWH. The location of the apple tree canopy may account for part of this difference. In an Iowa orchard, the duration of the dew period, which is the primary source of wetness during summer in the Midwest, was much shorter at the base of the canopy of mature semi-dwarfapple trees than at the top of the canopy, due to the presence of overhanging foliage and fruit in the apple canopy (Batzer et al., 2002b). Remote estimates, while sitespecific, do not account for this canopy effect. Therefore, such estimates would need to be calibrated in some manner in order to more accurately reflect leaf wetness conditions within apple tree canopies.

Reduced-RISK fungicides. Calendar-based applications of the strobi- 
Table 3. Effect of reduced-risk fungicides and a disease warning system on the incidence and severity of sooty blotch (SB) and flyspeck (FS) of apples in replicated experiments in $2002^{z}$

\begin{tabular}{|c|c|c|c|c|c|c|c|c|}
\hline \multirow[b]{3}{*}{ Treatment } & \multicolumn{4}{|c|}{ Illinois $^{y}$} & \multicolumn{2}{|c|}{ Wisconsin $\sin ^{x}$} & \multicolumn{2}{|c|}{ Iowa $^{x}$} \\
\hline & \multicolumn{2}{|c|}{ SB } & \multicolumn{2}{|c|}{ FS } & SB & FS & $\overline{S B}$ & FS \\
\hline & $\begin{array}{c}\text { Incidence } \\
(\%)\end{array}$ & $\begin{array}{l}\text { Severity }^{\mathrm{w}} \\
(\%)\end{array}$ & $\begin{array}{l}\text { Incidence } \\
(\%)\end{array}$ & $\begin{array}{c}\text { Severity } \\
(\%)\end{array}$ & \multicolumn{4}{|c|}{$\begin{array}{c}\text { Incidence } \\
(\%)\end{array}$} \\
\hline $\begin{array}{l}\text { Thiophanate-methyl + } \\
\text { captan (conventional) }\end{array}$ & $3.3 b^{v}$ & $0.04 \mathrm{ab}$ & $0.8 \mathrm{ab}$ & $0.01 \mathrm{a}$ & $0.0 \mathrm{a}$ & $0.5 \mathrm{a}$ & $0.0 \mathrm{a}$ & $0.0 \mathrm{a}$ \\
\hline $\begin{array}{l}\text { Thiophanate-methyl + } \\
\text { captan }(\text { on-site })\end{array}$ & $4.6 \mathrm{~b}$ & $0.05 \mathrm{~b}$ & $2.3 \mathrm{ab}$ & $0.02 \mathrm{a}$ & $0.0 \mathrm{a}$ & $0.2 \mathrm{a}$ & $0.2 \mathrm{a}$ & $0.2 \mathrm{ab}$ \\
\hline $\begin{array}{l}\text { Kresoxim-methyl } \\
\text { alternated with } \\
\text { thiophanate-methyl }\end{array}$ & & & & & & & & \\
\hline $\begin{array}{l}\text { + captan } \\
\text { Kresoxim-methyl } \\
\text { alternated with } \\
\text { thiophanate-methyl + } \\
\text { captan (on-site) }\end{array}$ & $\begin{array}{r} \\
+\quad 0.2 \mathrm{a}\end{array}$ & $0.00 \mathrm{a}$ & $0.2 \mathrm{a}$ & $0.01 \mathrm{a}$ & $0.0 \mathrm{a}$ & $11.8 \mathrm{~b}$ & $0.2 \mathrm{a}$ & $0.0 \mathrm{a}$ \\
\hline $\begin{array}{l}\text { Kresoxim-methyl } \\
\text { alternated with } \\
\text { thiophanate-methyl + } \\
\text { captan (site-specific) }\end{array}$ & $0.0 \mathrm{a}$ & $0.00 \mathrm{a}$ & $0.0 \mathrm{a}$ & $0.00 \mathrm{a}$ & $0.0 \mathrm{a}$ & $0.5 \mathrm{a}$ & $0.0 \mathrm{a}$ & $0.0 \mathrm{a}$ \\
\hline Potassium bicarbonate & $2.9 \mathrm{~b}$ & $0.04 \mathrm{ab}$ & $2.7 \mathrm{~b}$ & $0.03 \mathrm{a}$ & $2.4 \mathrm{~b}$ & $19.4 \mathrm{bc}$ & $0.0 \mathrm{a}$ & $0.0 \mathrm{a}$ \\
\hline Nontreated control & $43.8 \mathrm{c}$ & $0.65 \mathrm{c}$ & $44.2 \mathrm{c}$ & $0.54 \mathrm{~b}$ & $6.5 \mathrm{~b}$ & $25.6 \mathrm{c}$ & $0.0 \mathrm{a}$ & $0.2 \mathrm{ab}$ \\
\hline $\operatorname{LSD}(P<0.05)$ & 2.7 & 0.05 & 2.5 & 0.034 & 3.5 & 9.1 & NS & 0.51 \\
\hline
\end{tabular}

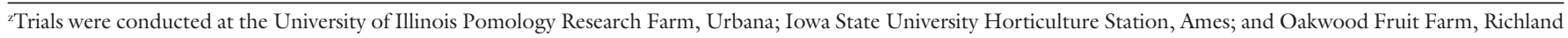
Center, Wis.

Mean percent of four replications; 120 apples per replication.

${ }^{\mathrm{x}}$ Mean percent of four replications; 100 apples per replication.

" Severity = percent surface area of fruit with SB or FS infection.

"Values within each column with a letter in common are not significantly different according to Fischer's protected least significant difference $(P=0.05)$. NS $=$ nonsignificant.

"Second-cover spray timing based on leaf wetness data from dataloggers placed in orchards (on-site) or based on leaf wetness data remotely estimated for the location of each orchard (site-specific) by SkyBit, Inc. (Bellefonte, Pa.).

Table 4. Location, apple cultivars, cover spray dates, and leaf wetness hours (LWH) in demonstration trials of a sooty blotch and flyspeck warning system in commercial apple orchard in Illinois, Iowa, and Wisconsin, 2001 and 2002.

\begin{tabular}{|c|c|c|c|c|c|c|c|c|c|c|}
\hline \multirow[b]{3}{*}{ State } & \multirow[b]{3}{*}{ Location } & \multirow[b]{3}{*}{ Variety } & \multirow{2}{*}{\multicolumn{2}{|c|}{$\begin{array}{c}2^{\text {nd }} \text { Cover spray } \\
{\left(\text { calendar }^{\mathrm{y}}\right)}\end{array}$}} & \multicolumn{4}{|c|}{ 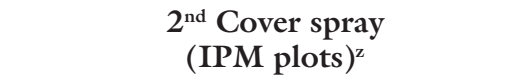 } & \multirow{2}{*}{\multicolumn{2}{|c|}{$\begin{array}{c}\text { Sprays } \\
\text { saved } \\
\text { (no.) }\end{array}$}} \\
\hline & & & & & \multicolumn{2}{|c|}{2001} & \multicolumn{2}{|c|}{2002} & & \\
\hline & & & 2001 & 2002 & Date & LWH & Date & LWH & 2001 & 2002 \\
\hline Illinois & Champaign & Golden Delicious & 18 May & 23 May & 22 June & 177 & 14 June & 203 & 3 & 2 \\
\hline Illinois & Sidney & Golden Delicious & 28 May & l June & 16 June & 175 & 24 June & 171 & 2 & 2 \\
\hline Illinois & Villa Grove & Golden Del/Smoothie & 19 May & 30 May & 29 July & 171 & $\mathrm{NA}^{\mathrm{x}}$ & NA & 6 & 7 \\
\hline Illinois & Sullivan & Golden Del/Smoothie & 23 May & 29 May & 16 July & $178^{w}$ & 4 July & 208 & 4 & 2 \\
\hline Illinois & Peoria & Ozark Gold & 7 June & 31 May & 16 June & 195 & 12 Aug. & 186 & 2 & 5 \\
\hline Iowa & Iowa Falls & Smoothie & l June & 28 June & 17 July & 175 & 6 Aug. & 175 & 3 & 2 \\
\hline Iowa & Nevada & Yellow Delicious & l June & 24 June & 22 June & 177 & 5 Aug. & 185 & 1 & 2 \\
\hline Iowa & Cambridge & Golden Delicious & 12 June & 12 June & 15 July & 94 & $\mathrm{NA}^{\mathrm{v}}$ & NA & 1 & NA \\
\hline Iowa & Ft. Dodge & Golden Delicious & 7 June & 13 June & 9 July & 180 & 31 July & 169 & 2 & 2 \\
\hline Iowa & Jefferson & Golden Delicious & 10 June & 15 June & 9 July & 170 & 23 July & 175 & 1 & 2 \\
\hline Wisconsin & Poynette & Honeygold & 2 June & 10 June & 22 June & 174 & 23 July & 182 & 1 & 5 \\
\hline Wisconsin & Waunakee & Golden Delicious & 8 June & 11 June & 11 Aug & 208 & 26 July & 149 & 5 & 3 \\
\hline Wisconsin & Fitchburg & Jonee & 5 June & 15 June & 15 June $^{\mathrm{u}}$ & 140 & 24 July & 218 & 1 & 3 \\
\hline Wisconsin & Cottage Grove & Golden Delicious & 11 June & 16 June & Never & 309 & 22 July & 135 & 4 & 3 \\
\hline
\end{tabular}

${ }^{\mathrm{z}} \mathrm{IPM}=$ the second-cover spray was applied after $175 \mathrm{~h}$ of wetness following the first-cover spray.

'Sprays applied on a biweekly schedule following the first-cover spray.

xOn 10 Sept., wetness hours were 164. Fruit were harvested on $25 \mathrm{Sept}$. Thus, no second-cover fungicide was applied.

wThe data logger at Sullivan orchard stopped recording data during 27 May to 5 June. We used the data from the orchard in Villa Grove (closest orchard to Sullivan) to measure the accumulated wetness hours.

The second cover spray was never applied, thus wetness hours accumulated to well over 175 by harvest.

"The IPM block was inadvertently sprayed along with rest of orchard [ $2 \mathrm{lb} / \mathrm{acre}\left(2.2 \mathrm{~kg} \cdot \mathrm{ha}^{-1}\right)$ a.i. captan] on 15 June, but then not sprayed again for the rest of the season. 
Table 5. Incidence and severity of sooty blotch (SB) and flyspeck (FS) in demonstration trials of a SBFS warning system in commercial apple orchards in Illinois, 2001 and 2002.

\begin{tabular}{|c|c|c|c|c|c|c|c|c|c|c|c|c|}
\hline \multirow[b]{3}{*}{ Location } & \multicolumn{6}{|c|}{ Sooty blotch } & \multicolumn{6}{|c|}{ Flyspeck $^{z}$} \\
\hline & \multicolumn{3}{|c|}{ Incidence (\%) } & \multicolumn{3}{|c|}{ Severity $^{y}(\%)$} & \multicolumn{3}{|c|}{ Incidence (\%) } & \multicolumn{3}{|c|}{ Severity (\%) } \\
\hline & Grower & $\mathrm{IPM}^{\mathrm{x}}$ & $\operatorname{LSD}^{\mathrm{w}}$ & Grower & IPM & LSD & Grower & IPM & LSD & Grower & IPM & LSD \\
\hline \multicolumn{13}{|l|}{2001} \\
\hline Champaign & $3.0 \mathrm{a}^{\mathrm{v}}$ & $1.5 \mathrm{a}$ & NS & $0.03 \mathrm{a}$ & $0.05 \mathrm{a}$ & NS & $2.3 \mathrm{a}$ & $5.0 \mathrm{~b}$ & 2.1 & $0.03 \mathrm{a}$ & $0.05 \mathrm{~b}$ & 0.02 \\
\hline Sidney & $10.0 \mathrm{a}$ & $7.5 \mathrm{a}$ & NS & $0.15 \mathrm{a}$ & $0.15 \mathrm{a}$ & NS & $3.2 \mathrm{a}$ & $3.7 \mathrm{a}$ & NS & $0.05 \mathrm{a}$ & $0.07 \mathrm{a}$ & NS \\
\hline Villa Grove & $2.8 \mathrm{a}$ & $11.0 \mathrm{~b}$ & 2.9 & $0.07 \mathrm{a}$ & $0.38 \mathrm{~b}$ & 0.12 & $2.2 \mathrm{a}$ & $8.5 \mathrm{~b}$ & 2.5 & $0.04 \mathrm{a}$ & $0.20 \mathrm{~b}$ & 0.07 \\
\hline Sullivan & $32.8 \mathrm{a}$ & $43.0 \mathrm{~b}$ & 5.8 & $0.67 \mathrm{a}$ & $1.77 \mathrm{~b}$ & 0.26 & $36.0 \mathrm{a}$ & $45.8 \mathrm{~b}$ & 5.6 & $1.21 \mathrm{a}$ & $2.54 \mathrm{~b}$ & 0.35 \\
\hline Peoria & $0.0 \mathrm{a}$ & $0.0 \mathrm{a}$ & NS & $0.00 \mathrm{a}$ & $0.00 \mathrm{a}$ & NS & $0.0 \mathrm{a}$ & $0.0 \mathrm{a}$ & NS & $0.00 \mathrm{a}$ & $0.00 \mathrm{a}$ & NS \\
\hline \multicolumn{13}{|l|}{2002} \\
\hline Champaign & $0.0 \mathrm{a}$ & $4.2 \mathrm{~b}$ & 1.6 & $0.00 \mathrm{a}$ & $0.05 \mathrm{~b}$ & 0.02 & $0.0 \mathrm{a}$ & $0.0 \mathrm{a}$ & NS & $0.00 \mathrm{a}$ & $0.00 \mathrm{a}$ & NS \\
\hline Sidney & $17.0 \mathrm{a}$ & $24.8 \mathrm{~b}$ & 4.6 & $0.20 \mathrm{a}$ & $0.48 \mathrm{~b}$ & 0.16 & $3.0 \mathrm{a}$ & $2.6 \mathrm{a}$ & NS & $0.03 \mathrm{a}$ & $0.03 \mathrm{a}$ & NS \\
\hline Villa Grove & $0.0 \mathrm{a}$ & $0.0 \mathrm{a}$ & NS & $0.00 \mathrm{a}$ & $0.00 \mathrm{a}$ & NS & $0.0 \mathrm{a}$ & $0.0 \mathrm{a}$ & NS & $0.00 \mathrm{a}$ & $0.00 \mathrm{a}$ & NS \\
\hline Sullivan & $0.2 \mathrm{a}$ & $0.8 \mathrm{a}$ & NS & $0.01 \mathrm{a}$ & $0.01 \mathrm{a}$ & NS & $0.0 \mathrm{a}$ & $0.7 \mathrm{~b}$ & 0.65 & $0.00 \mathrm{a}$ & $0.06 \mathrm{a}$ & 0.06 \\
\hline Peoria & $0.0 \mathrm{a}$ & $0.0 \mathrm{a}$ & NS & $0.00 \mathrm{a}$ & $0.00 \mathrm{a}$ & NS & $0.0 \mathrm{a}$ & $0.0 \mathrm{a}$ & NS & $0.00 \mathrm{a}$ & $0.00 \mathrm{a}$ & NS \\
\hline
\end{tabular}

${ }^{\mathrm{z}}$ Mean percent of 10 trees; 60 apples per tree.

${ }^{y}$ Severity $=$ percent surface area of fruit with SB or FS infection.

${ }^{x} \mathrm{IPM}=$ the second-cover spray was applied after $175 \mathrm{~h}$ of wetness following the first-cover spray.

"Fisher's protected least significant difference at $P<0.05$. NS $=$ nonsignificant.

"Values followed with the letter within each year, location, and disease combination are not significantly different.

Table 6. Incidence of sooty blotch (SB) and fly speck (FS) in demonstration trials of a SBFS warning system in commercial apple orchards in Iowa, 2001 and 2002.

\begin{tabular}{|c|c|c|c|c|c|c|c|c|c|}
\hline \multirow[b]{3}{*}{ Location } & \multirow{2}{*}{\multicolumn{3}{|c|}{$\frac{2001}{{\text { Incidence } S B F S^{z}(\%)}^{2}}$}} & \multicolumn{6}{|c|}{2002} \\
\hline & & & & \multicolumn{3}{|c|}{ Incidence $\mathrm{SB}^{\mathrm{z}}(\%)$} & \multicolumn{3}{|c|}{ Incidence $\mathrm{FS}^{\mathrm{z}}(\%)$} \\
\hline & Grower & IPM $^{y}$ & $\mathrm{LSD}^{\mathrm{x}}$ & Grower & IPM & LSD & Grower & IPM & LSD \\
\hline Iowa Falls & $0.5 \mathrm{a}^{\mathrm{w}}$ & $0.1 \mathrm{a}$ & 0.08 & $0.0 \mathrm{a}$ & $0.0 \mathrm{a}$ & NS & $0.0 \mathrm{a}$ & $0.0 \mathrm{a}$ & NS \\
\hline Nevada & $5.0 \mathrm{a}$ & $6.6 \mathrm{~b}$ & 0.16 & $1.3 \mathrm{a}$ & $5.2 \mathrm{a}$ & NS & $0.0 \mathrm{a}$ & $2.3 \mathrm{a}$ & NS \\
\hline Cambridge & $0.0 \mathrm{a}$ & $0.0 \mathrm{a}$ & NS & $\mathrm{NA}^{\mathrm{v}}$ & NA & NA & $\mathrm{NA}^{\mathrm{v}}$ & NA & NA \\
\hline Ft. Dodge & $0.0 \mathrm{a}$ & $0.0 \mathrm{a}$ & NS & $0.0 \mathrm{a}$ & $0.0 \mathrm{a}$ & NS & $0.0 \mathrm{a}$ & $0.0 \mathrm{a}$ & NS \\
\hline Jefferson & $0.0 \mathrm{a}$ & $0.0 \mathrm{a}$ & NS & $0.0 \mathrm{a}$ & $0.0 \mathrm{a}$ & NS & $0.0 \mathrm{a}$ & $0.0 \mathrm{a}$ & NS \\
\hline
\end{tabular}

${ }^{2}$ Mean percent of 10 trees; 50 apples per tree.

yIPM $=$ the second-cover spray was applied after $175 \mathrm{~h}$ of wetness following the first-cover spray.

'Fisher's protected least significant difference at $P<0.05$. Ns = nonsignificant.

walues followed by the same letter within each year, location, and disease combination are not significantly different.

${ }^{\mathrm{v}} \mathrm{NA}=$ the second cover spray was never applied at this orchard, thus wetness hours accumulated to well over 175 by harvest.

Table 7. Incidence of sooty blotch (SB) and fly speck (FS) in demonstration trials of a SBFS warning system in commercial apple orchards in Wisconsin, 2001 and 2002.

\begin{tabular}{|c|c|c|c|c|c|c|c|c|c|c|c|c|}
\hline \multirow[b]{3}{*}{ Location } & \multicolumn{6}{|c|}{2001} & \multicolumn{6}{|c|}{2002} \\
\hline & \multicolumn{3}{|c|}{ Incidence $\mathrm{SB}^{\mathrm{z}}(\%)$} & \multicolumn{3}{|c|}{ Incidence $\mathrm{FS}^{\mathrm{z}}(\%)$} & \multicolumn{3}{|c|}{ Incidence $\mathrm{SB}^{\mathrm{z}}(\%)$} & \multicolumn{3}{|c|}{ Incidence FS (\%) } \\
\hline & Grower & $\mathrm{IPM}^{\mathrm{y}}$ & LSD $^{x}$ & Grower & IPM & $\overline{\text { LSD }}$ & Grower & IPM & LSD & Grower & IPM & LSD \\
\hline Poynette & $17.6 \mathrm{a}^{\mathrm{w}}$ & $20.8 \mathrm{a}$ & NS & $4.0 \mathrm{a}$ & $14.0 \mathrm{~b}$ & 5.1 & $23.0 \mathrm{a}$ & $70.6 \mathrm{~b}$ & 14.1 & $70.0 \mathrm{a}$ & $79.8 \mathrm{a}$ & NS \\
\hline Waunakee & $44.2 \mathrm{a}$ & $82.0 \mathrm{~b}$ & 14.1 & $43.1 \mathrm{a}$ & $72.0 \mathrm{~b}$ & 17.5 & $32.2 \mathrm{a}$ & $44.8 \mathrm{a}$ & NS & $20.0 \mathrm{a}$ & $18.6 \mathrm{a}$ & NS \\
\hline Fitchburg & $11.8 \mathrm{a}$ & $25.4 \mathrm{~b}$ & 12.2 & $48.0 \mathrm{a}$ & $48.8 \mathrm{a}^{\mathrm{v}}$ & NS & $0.0 \mathrm{a}$ & $1.2 \mathrm{a}$ & NS & $2.8 \mathrm{a}$ & $6.0 \mathrm{a}$ & NS \\
\hline Cottage Grove & $27.8 \mathrm{a}$ & $90.2 \mathrm{~b}$ & 23.5 & $19.2 \mathrm{a}$ & $84.6 \mathrm{~b}$ & 12.0 & $4.6 \mathrm{a}$ & $5.4 \mathrm{a}$ & NS & $2.0 \mathrm{a}$ & $4.0 \mathrm{a}$ & NS \\
\hline
\end{tabular}

${ }^{2}$ Mean percent of 10 trees; 50 apples per tree.

yIPM $=$ the second-cover spray was applied after $175 \mathrm{~h}$ of wetness following the first-cover spray.

'Fisher's protected least significant difference at $P<0.05$. NS $=$ nonsignificant.

walues followed by the same letter within each year, location, and disease combination are not significantly different.

${ }^{v}$ IPM block was inadvertently sprayed along with rest of orchard [ $2 \mathrm{lb} /$ acre $\left(2.2 \mathrm{~kg} \cdot \mathrm{ha}^{-1}\right)$ a.i. captan] on 15 June but then not sprayed again for the rest of the season.

lurin fungicides kresoxim-methyl and trifloxystrobin provided control of SBFS equal to that of the conventional control (benomyl or thiophanate-methyl plus captan) at 11 of 12 site-years (Tables 2 and 3). In Wisconsin in 2002, one of the eight trees treated with kresoximmethyl had a very high incidence of FS, which raised the mean incidence of FS at that location. When data from that tree were excluded from the analysis, FS incidence was $3.2 \%$ and not significantly different from the conventional control. Overall, when used in alternation with benomyl or thiophanate-methyl plus captan, trifloxystrobin and kresoximmethyl reduced the incidence of SBFS to acceptable levels. Potassium bicarbonate (Kaligreen) controlled SBFS better than the unsprayed control (Tables 2 and
$3)$, but it was clearly less effective than strobilurins or conventional fungicides. Nevertheless, potassium bicarbonate may be useful in organic orchards where use of synthetic fungicides are prohibited.

Demonstration trials. The on-site warning system saved one to six (mean 2.6) and two to seven (mean 3.1) sprays per season in 2001 and 2002, respec- 
tively (Table 4). However, in 2001, three Illinois, one Iowa, and four Wisconsin orchards had higher incidence of SB and/or FS in the plots sprayed according to the warning system than in the plots that received the growers' typical spray schedules (Tables 5, 6, and 7). Also, in 2002, SB and/or FS incidence was significantly higher in the IPM plots at three Illinois and one Wisconsin orchards (Tables 5 and 7). Overall, the incidence of SB and/or FS was higher in IPM plots than conventional plots in 12 of 28 site-years. In nine out of these 12 cases, the second-cover spray was applied after the 175-h threshold. Therefore, it appears that delayed application of the secondcover spray has been the main reason for the higher incidence of SB or FS in the warning-system plots. Other possible reasons for higher incidence of $\mathrm{SB}$ or FS in the IPM plots could be poor spray coverage in inadequately pruned trees. Because our wetness-based spray program was effective in replicated trials in research orchards in Illinois and Iowa (Tables 2 and 3 ), we suspect that poor pruning may have caused the failures at commercial orchards in these states. Likewise, in Wisconsin, failure in IPM plots (e.g., FS at Waunakee in 2001) was associated with dense tree canopies. The extra fungicide sprays on conventional calendar-based system may have compensated for poor pruning. Although incidence of SBFS was higher in the IPM plots than the conventional control calendar-based plots in some of the orchards, severity of disease was very low (mostly $<1 \%$ ) which should not have a significant negative impact on the value of fruit.

Overall, growers in Illinois and Iowa were very pleased with the success of the disease prediction system. Several growers have purchased their own sensors, and many others are interested in cooperating in future trials of the system. In Wisconsin, despite mixed success, some growers intend to use the system, with the understanding that adequate pruning is essential, especially in upper canopies where wetness duration is longer and spray coverage tends to be incomplete. Saving sprays by using the disease prediction system and integrating reduced-risk fungicides for control of SBFS will be economical and reduce exposure of workers, consumers, and the environment to fungicides.

\section{Literature cited}

Andrews, J.H., J.K. O'Mara, and P.S. McManus. 2001. Methionine-riboflavin and potassium bicarbonate-polymer sprays control apple flyspeck and sooty blotch. Plant Health Progress. 30 Apr. 2003. <http:// www.plantmanagementnetwork.org/pub/ $\mathrm{php} / \mathrm{research} / 200 \mathrm{l} / \mathrm{fssb} />$.

Batzer, J.C., M.L. Gleason, T. Harrington, and W. Chen. 2002a. Expansion of the sooty blotch and flyspeck complex on apple using ribosomal DNA. Phytopathology 92(6):S6 (abstr.).

Batzer, J.C., M.L. Gleason, K.J. Koehler, and S.E. Taylor. 2002b. Variation in leaf wetness duration within apple tree canopies. Phytopathology 92(6):S6 (abstr.).

Bervejilo, O., M.S. Dhatt, and W.D. Gubler. 2000. Evaluation of fungicides for control of grape powdery mildew, 1999. Fungicide Nematicide Tests 55:94.

Bessin, R.T., P.S. McManus, G.R. Brown, and J.G. Strang. 1998. Midwest tree fruit pest management handbook. Univ. Ky., Lexington.

Brown, E.M. and T.B. Sutton. 1995. An empirical model for predicting the fist symptoms of sooty blotch and flyspeck of apples. Plant Dis. 79:1165-1168.

Cooley, D.A. and W.R. Autio. 1997. Disease-management components of advanced integrated pest management in apple orchards. Agr. Ecosystem Environ. 66:31-40.

Cooley, D.R., R.J. Prokopy, J. Mason, and S. Weight. 1995. Effects of pesticides on pest ecology in blocks of scab-resistant apple cultivars. Fruit Notes (Winter): 16-19.

Gleason, M.L., M.K. Ali, P.A. Domoto, D.R. Lewis, and M.D. Duffy. 1994. Comparing integrated pest management and protectant strategies for control of apple scab and codling moth in an Iowa apple orchard. HortTechnology 4:136-144.

Gleason, M.L., M. Babadoost, P.S. McManus, S.N. Wegulo, and S.J. Helland. 2002. Performance of a warning system for sooty blotch and flyspeck on apple using on-site wetness measurements and site-specific wetness estimates. Phytopathology 92(6): S29 (abstr.)

Gleason, M.L., S.K. Parker, R.E. Pitblado, X.R. Latin, D. Spranzini, R.V. Hazzard, M.J. Malletta, W.P. Cowling, Jr., and D.L. Biederstedt. 1997. Validation of a commercial system for remote estimation of wetness duration. Plant Dis. 81:825-829.

Gleason, M.L., S.N. Wegulo, J.C. Batzer, and P.A. Domoto. 2000. Performance of SkyBit data input to disease-warning model for sooty blotch and flyspeck, 1999. Fungicide Nematicide Tests 55:5.
Hartman, J.R. 1995 Evaluation of fungicide timing for sooty blotch and flyspeck control, 1994. Fungicide Nematicide Tests 50:10.

Hickey, K.D. 1960. The sooty blotch and flyspeck diseases of apple with emphasis on variation within Gloeodes pomigena (Schow.) Colby. PhD diss. Pa. State Univ., Univ. Park, Pa.

Johnson, E.M., T.B. Sutton, and C.S. Hodges. 1996. Peltaster fructicola: A new species in the complex of fungi causing apple sooty blotch disease. Mycologia 88: 114-120.

Kaplan, M.L., J.W. Zack, V.C. Wong, and J.J. Tucillo. 1982. Initial results from an atmospheric simulation system and comparison with an AVE-SESAME I data set. Monthly Weather Rev. 110:1564.

Kirby, R.S. 1954. Relation of rainfall to occurrence of apple scab and sooty blotch. Phytopathology 44:495 (abstr.).

Lunden, L.D. and G.G. Grove. 2002. Peach powdery mildew control, 2001. Fungicide Nematicide Tests 57:STF20.

Rosenberger, D.A. 1994. Summer disease control on apples. Annu. Rpt. State Hort. Soc. Mich. 124:80-86.

Rosenberger, D.A., F.W. Meyer, and C.A. Ahlers. 2000. Evaluation of strobilurin and other new fungicides for controlling apple diseases, 1999. Fungicide Nematicide Tests $55: 28$

Russo, J.M. 2000. Weather forecasting for IPM, p. 453-473 In: G.G. Kennedy and T.B. Sutton (eds.). Emerging techniques for integrated pest management: Concepts, research, and implementation. APS Press, St. Paul, Minn.

Russo, J.M., J.W. Travis, and D.L. Truxall. 1996. Simulated mesoscale weather data as input into an apple expert system, p. 334335 In: Proc. Conf. Agr. For. Meteorol., 22 ${ }^{\text {nd }}$ Amer. Meteorol. Soc., Boston, Mass.

Smigell, C.G. and J.R. Hartman. 1997. Evaluation of fungicide timing for sooty blotch and flyspeck control, 1996. Fungicide Nematicide Test 52:31.

Sutton, T.B., O. Anas, and S. Tang. 2000. Fungicide treatments for summer disease control, 1999. Fungicide Nematicide Tests $55: 34$.

Weinzierl, R., M. Babadoost, and M. Kushad. 2002. Commercial tree fruit spray guide, 2003. Univ. Ill. Ext. Serv., ICSG4-03.

Williamson, S.M. and Sutton, T.B. 2000. Sooty blotch and flyspeck of apple: Etiology, biology, and control. Plant Dis. 84: 714-724. 